\title{
Three-Year Follow-up of Smoking Prevalence, Knowledge, Attitudes and Beliefs Among Pharmacy Students at UMPhST, Targu Mures
}

\author{
ZITA FAZAKAS ${ }^{1}$, ENIKO NEMES-NAGY1*, ERZSEBET FOGARASI ${ }^{2}$, ZOLTAN PREG ${ }^{3}$, MIHALY IMRE LASZLO ${ }^{4}$, HAJ NAL KELEMEN ${ }^{5}$, \\ MARTA GERMAN-SALLO ${ }^{6}$, PETER BALAZS ${ }^{7}$, MELINDA SZEKELYY ${ }^{8}$, VANDA ROXANA NIMIGEAN ${ }^{9}$, KRISTIE FOLEY $^{10}$, ZOLTAN ABRAM ${ }^{11}$, \\ PAL ISTVAN KIKELI ${ }^{4}$ \\ ${ }^{1}$ University of Medicine, Pharmacy, Science and Technology of Targu Mures, Faculty of Pharmacy, Department of Biochemistry \\ and Environmental Chemistry, 38 Gh. Marinescu Str., 540139, Targu Mures, Romania \\ ${ }^{2}$ University of Medicine, Pharmacy, Science and Technology of Targu Mures, Faculty of Pharmacy, Department of Toxicology and \\ Biopharmacy, 38 Gh. Marinescu Str., 540139, Targu Mures, Romania \\ 3 University of Medicine, Pharmacy, Science and Technology of Targu Mures, Faculty of Medicine, Department of Family \\ Medicine, 38 Gh. Marinescu Str., 540139, Targu Mures, Romania \\ ${ }^{4}$ Procardia Medical Unit, 3 M. Eminescu Str., 540043, Targu Mures, Romania \\ ${ }^{5}$ University of Medicine, Pharmacy, Science and Technology of Targu Mures, Faculty of Pharmacy, Department of Pharmaceutical \\ Chemistry, 38 Gh. Marinescu Str., 540139, Targu Mures, Romania \\ ${ }^{6}$ University of Medicine, Pharmacy, Science and Technology of Targu Mures, Faculty of Medicine, Department of Internal \\ Medicine III, 38 Gh. Marinescu Str., 540139, Targu Mures, Romania \\ ${ }^{7}$ Semmelweis University, Faculty of Medicine, Department of Public Health, 26 Ulloi ut, 1085, Budapest, Hungary \\ ${ }^{8}$ University of Medicine, Pharmacy, Science and Technology of Targu Mures, Faculty of Dental Medicine, Department of \\ Morphology of Teeth and Dental Arches; Technology of Dental Prosthesis and Dental Materials, 38 Gh. Marinescu Str., 540139, \\ Targu Mures, Romania \\ ${ }^{9}$ University of Medicine and Pharmacy Carol Davila Bucuresti, Faculty of Dental Medicine, Department of Oral Rehabilitation, \\ 8 Eroilor Sanitari Str., 050474, Bucuresti, Romania \\ ${ }^{10}$ Wake Forest University Medical School, Department of Social Sciences and Health Policy, Cancer Prevention and Control \\ Program, 1834 Wake Forest Rd, Winston Salem, NC 27109, USA \\ ${ }^{11}$ University of Medicine, Pharmacy, Science and Technology of Targu Mures, Faculty of Medicine, Department of Hygiene, $38 \mathrm{Gh}$. \\ Marinescu Str., 540139, Targu Mures, Romania
}

Objectives of the study were to investigate the smoking prevalence, knowledge, attitudes and beliefs among Romanian pharmacy students. Surveys were conducted among pharmacy students during 20142016. A locally-adapted version of the Global Health Professional Students Survey was used, which is a selfadministered questionnaire developed by the World Health Organization to assess smoking behaviors and attitudes among health professional students. The study was conducted at the University of Medicine, Pharmacy, Science and Technology (UMPhST) of Targu Mures, Romania (UMPh of Targu Mures, at that time). All pharmacy students ( $1^{1^{s t}} 5^{\text {th }}$ years) were invited to participate in this study. In the first year of the study 414, during the second year 396, and in the third year a number of 449 pharmacy students were enrolled in our survey. There were assessed the prevalence of current cigarette smoking and other tobacco use in pharmacy students, defined as smoking or other tobacco use at least once in the past 30 days, and also the opinion, knowledge and attitude of these students regarding the tobacco-related legislation. 29.5\% of the evaluated pharmacy students were current smokers in the first year of the study, $26.1 \%$ in the second year and $29.9 \%$ in the third year of the study. $45.7 \%$ of the enrolled pharmacy students used other tobacco products in the past 30 days in 2014, 41.5\% in 2015 and 44.4\% in 2016. Among current smokers desire to quit was high, ranging between 93.6-96.4\%. Support for tobacco-banning legislation among pharmacy students showed significant increase in the last year of our study. This study contributes to knowledge on to bacco use among pharmacy students at the UMPhST in Targu Mures, Romania. Our results suggest that smoking prevalence in this cohortis low and that these health professional students are supportive of tobacco control policies. At the end of study period the National Clean Air Law nr. 15/2016 was implemented in Romania and our university became the first smoke-free medical university in the country.

Keywords: pharmacy students, University of Medicine, Pharmacy, Science and Technology, smoke-free medical university, prevalence of smoking, quit smoking

Tobacco smoking is a global epidemic [1], with the majority of smokers living in low- and middle income countries. Health professionals play an important role in reducing the incidence of smoking-related diseases by discouraging smoking initiation and encouraging cessation among patients who smoke [2, 3]. Likewise, health professional faculties are ideally positioned to advise and educate health professional students about the dangers of smoking and to teach practical skills on how to help the students' future patients quit smoking [4]. One of the strategies to reduce smoking-related morbidity and mortality is to encourage the involvement of health professionals in tobacco-use prevention and cessation counsel $[4,5]$. Medical professionals who smoke are more likely to hold attitudes that prevent them from providing patients with smoking cessation counselling and support $[4,6]$. Thus, it is suggested that healthcare students should

* email: eniko.nemes-nagy@umfst.ro, Phone: 0742-273661 All authors have equal contributions to this paper and thus are main authors 
be exposed to tobacco control strategies and education from the outset of their training $[4,7]$.

In 2005, the World Health Organization (WHO), the US Centres for Disease Control and Prevention, and the Canadian Public Health Association developed and administered the Global Health Professionals Survey (GHPS) in 10 countries [8] to collect data on tobacco use and cessation counselling among health-profession students. The GHPSS study collected data from 47 countries during 2005-2008 [9]. Romanian, however, has not participated in the GHPSS survey, leaving a gap in our understanding of tobacco use and training among health professional students in Romania.

The present study aimed to fill this gap by using an adapted version of the GHPSS (Global Health Professions Student Survey) to assess the following:

-smoking prevalence, attitudes, beliefs and knowledge among pharmacy students in University of Medicine, Pharmacy, Science and Technology (UMPhST) of Targu Mures, Romania;

-smoking habits at UMPhST and the students' exposure to passive smoking;

-necessity of tobacco-related education in the curriculum of future pharmacy health professionals.

The study was designed because in Romania this was the first survey conducted throughout three years to collect information from health profession students in different contexts about their tobacco use and knowledge towards smoking cessation policies and programmes.

\section{Experimental part}

This three-year study was conducted at the University of Medicine, Pharmacy, Science and Technology of Targu Mures, Romania. Undergraduate health professional students in medicine, dentistry, pharmacy and nursing were asked to complete a self-administered questionnaire each year of the studied period. The questionnaires were distributed by student volunteers who approached students in their classroom and asked them to participate. The study was approved by the Research Ethics Committee of the university and teachers were asked for their permission prior to distributing the questionnaires. The surveys were completed between March and May 2014 and repeated in 2015 and 2016, respectively. All pharmacy students present on the date of data collection were invited to participate. The study design model is presented in figure 1 [10].

An adapted version of the Global Health Professions Student Survey (GHPSS) questionnaire was used which was developed by the WHO. The original English-language questionnaire consisted of 47 questions divided into six sections (indicated as I-VI). The original version of the GHPSS questionnaire was translated into Romanian and Hungarian language by an expert in English-RomanianHungarian translation. We also added two additional sections (VII and VIII) that were specific to the goals of the broader study to promote a smoke-free university. The final form of the Romanian/Hungarian questionnaire included the following sections: 1-5);

I.Demographics (age, gender, year of study) (questions

II.Tobacco use prevalence among health professional students (questions 6-17);

III.Behavior/cessation (smoking habits, willingness to stop, opinions abouthealthcare professionals who used to smoke) (questions 18-25);

IV.Exposure to environmental tobacco smoke (time spent with people who smoke in places other than home) (questions 26-29);

V.Attitudes (opinions about non-smoking policies and laws, and about the role of healthcare professionals) (questions 30-40);

VI.Curriculum-training (formal training in smoking cessation techniques on the medical curriculum and knowledge about methods - pharmacological or counselling techniques - for providing help to quitsmoking) (questions 41-47);

VII.Smoke free university (questions 48-59);

VIII.Smoking habits at UMPhST Targu Mures (questions 60-72).

\section{STUDYDESIGN MODE}

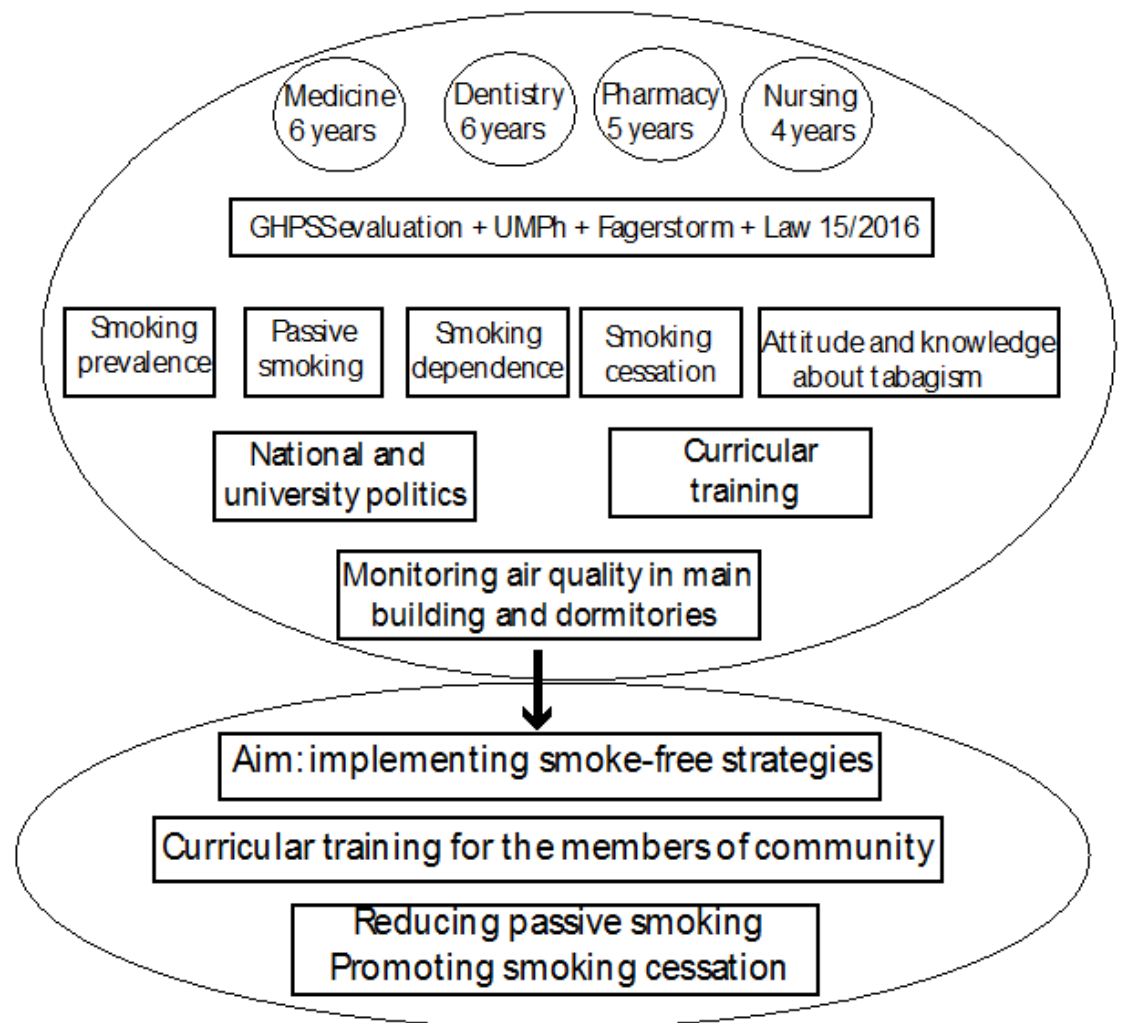

Fig. 1. Study design presents the objectives and aims 
The purpose of this study focused on tobacco use prevalence among pharmacy students, their attitudes towards tobacco control policies and laws, the role of health professionals in supporting smoking cessation, and evaluation of smoking habits at UMPhST, Targu Mures.

This study was approved by the Research Ethics Committee of the UMPhST of Targu Mures. Students were explained the objectives of the study and emphasized that participation was voluntary and anonymous. Written consent was obtained from each respondent and confidentiality assured.

Descriptive analyses were performed using frequencies, percentages, frequency tables for categorical variables and mean \pm standard deviation (SD). For the bivariate analysis t-tests and chi-square tests were performed to evaluate differences for categorical variable. The level of significance was set at $p<0.05$. Data were analysed with the IBM SPSS (Statistical Package for Social Sciences) software version 22 and GraphPad InStat (Fischer's test).

\section{Results and discussions}

The response rate of pharmacy students was $95.5 \%$. The questionnaire was filled in by 414 pharmacy students in 2014, 396 students in 2015 and 449 in 2016. A total number of 1259 questionnaires were filled in by pharmacy students during the three years of the study. Among pharmacy students who responded to the survey, $85 \%$ were female and $95.1 \%$ were below the age of 24 years. $26-30 \%$ of them were current, how ever non-daily regular smokers (table 1).

Almost all smoking students (94-96\%) indicated that they would like to quit smoking. The tobacco use prevalence of pharmacy students, their opinion about tobacco use and banning were included in table 2.

About two third of the investigated students reported never smoking, which did not changed during the study period. There is a ratio of 1:1 of students who smoked and have not smoked cigarettes in the university campus, such as courtyard, buffet, library, gym hall and canteen. Statistically non-significant difference has been obtained

\begin{tabular}{|l|l|l|l|}
\hline \multirow{2}{*}{ Variables } & \multicolumn{3}{|c|}{$\mathbf{N}(\%)$} \\
\cline { 2 - 4 } & $\mathbf{1}^{\text {st }}$ year 2014 & $\mathbf{2}^{\text {nd }}$ year 2015 & $\mathbf{3}^{\text {rd }}$ year 2016 \\
\hline $\begin{array}{l}\text { Age } \\
<24 \\
\geq 25\end{array}$ & $\begin{array}{c}397(95.9) \\
17(4.1)\end{array}$ & $\begin{array}{c}377(95.2) \\
19(4.8)\end{array}$ & $\begin{array}{c}423(94.2) \\
26(5.8)\end{array}$ \\
\hline $\begin{array}{l}\text { Gender } \\
\text { Female }\end{array}$ & $355(85)$ & $342(86.4)$ & $381(84.3)$ \\
Male & $59(15)$ & $54(13.6)$ & $68(15.7)$ \\
\hline $\begin{array}{l}\text { Year of attendance } \\
1^{\circ}-2^{\circ}\end{array}$ & $175(42.2)$ & $196(49.5)$ & $198(41.6)$ \\
$3^{\circ}-5^{\circ}$ & $239(57.8)$ & $200(50.5)$ & $251(58.4)$ \\
\hline Total & $414(100)$ & $396(100)$ & $449(100)$ \\
\hline
\end{tabular}

Table 1

CHARACTERISTICS OF THE COHORT OF PHARMACY STUDENTS ATTENDING THE UNIVERSITY OF MEDICINE, PHARMACY, SCIENCE AND TECHNOLOGY, TARGU-MURES, ROMANIA (2014-2016)

Table 2

TOBACCO USE PREVALENCE AND STUDENTS ATTITUDE AGAINST SMOKING OF PHARMACY STUDENTS, UNIVERSITY OF MEDICINE AND PHARMACY, SCIENCE AND TECHNOLOGY OF TARGU MURES

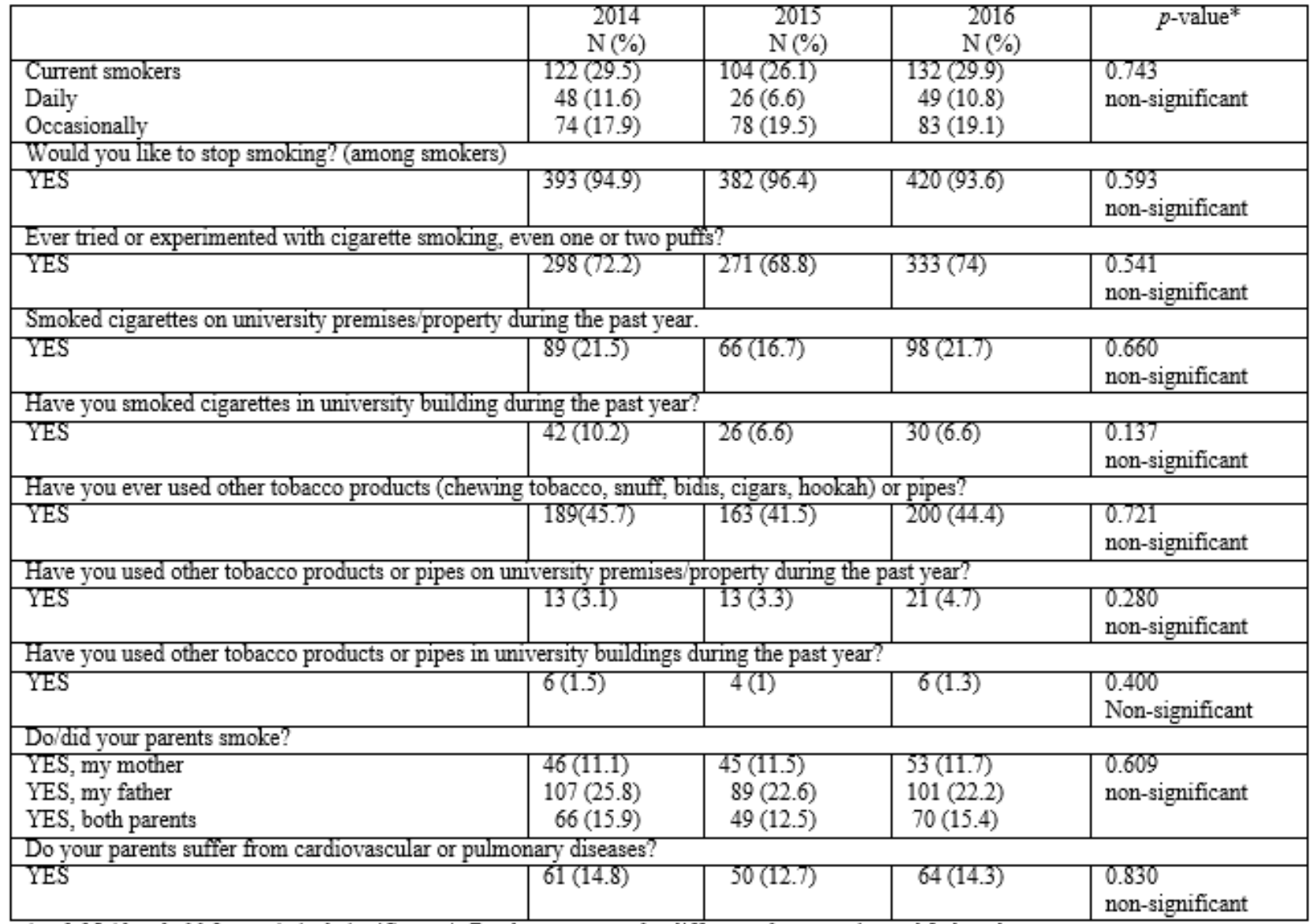

${ }^{8} p=0.05$ (threshold for statistical significance). $\mathrm{P}$ value concerns the difference between 1 st and 3rd study years. 
during the three years of follow-up between the answers: Yes-No. It was necessary to introduce the Smoke-Free Medical University Project in UMPhST, which was enforced by the National Law 15/2016, implemented a month before the last survey took place. There has been no significant improvement in pharmacy students' attitude on short term after that law was introduced in Romania and in the university emphatic awareness was requested by this respect.

Smoking was forbidden in the buildings of our university when the survey started, in 2014. The more restrictive National Clean Air Law nr. 15/2016, which was applied from March 2016, updated the former legislation. A slight amendment in students' attitude towards smoking could be observed during the three years of the study $(10.2 \%$ in $2014,6.6 \%$ in 2015 and $6.6 \%$ in 2016) concerning smoked cigarettes in the university building. In 2016 UMPhST officially became the first Smoke-Free Medical University in Romania.

Experimenting with other tobacco products is present in case of half of the surveyed pharmacy students (45.7\% in $2014,41.5 \%$ in 2015 and $44.4 \%$ in 2016).

Significant changes were notobserved neither regarding the percentage of those who have used other tobacco products on the territory of university (3.1\% in 2014, 3.3\% in 2015 and $4.7 \%$ in 2016), nor within the university buildings (1.5\% in 2014, $1.0 \%$ in $2015,1.3 \%$ in 2016), respectively. As the negative effects of cigarette smoking are already known, tobacco companies offer for sale other tobacco products for which they can create uncertainty about the effects of addiction, respectively the less harmful effects or the absence of passive smoking in some of these products. Worldwide there is an increase in sales of these tobacco replacement products, however our university does not fall into this world trend.

There is a 1:1 ratio of students whose parents are smokers and non-smokers. No change was observed during these three years regarding the percentage of parents suffering from cardiovascular or pulmonary diseases (14.8\% in 2014, $12.7 \%$ in 2015, and $14.3 \%$ in 2016).
The opinion of students about tobacco use and information about smoking cessation are summarized in table 3.

Across all years of the study, students strongly support the restrictions on sale of tobacco products to minors. The majority also support the prohibition of tobacco advertising.

Students highly agreed restrictions on smoking in restaurants $(p<0.05)$, in discos, bars, cafes $(p<0.0001)$, and in all enclosed public spaces $(p<0.05)$ with a significant increase in support for this measure in 2016 as compared to 2014.

More than $92 \%$ of the students (table $3, \mathrm{Q} 62$ ) reported that they agree to restrict smoking in the central building of the university, student dormitories and hospitals grounds. Some (around 20\%, Q60), however, thought the students smoked only at places where smoking is allowed.

Two years of cross-sectional study conducted at UMPhST and also collaboration with the government's representatives led to the implementation of the Law no. $15 / 2016$ in Romania, the law for the prevention and combating of tobacco products [11], which provides [12] banning smoking in enclosed public spaces.

During all three years of study students have expressed their desire to get specific training on cessation techniques during their university years (Q35), they would like to serve as role models for their patients and the public (Q36), they would like also to advise their patients to quit smoking (Q37) and tobacco products (Q38). Statistically no significant differences could be observed with this respect (table 4).

In spite of having the tobaccology optional course approved only for general medicine and nurse students, significant increase could be observed in 2016 regarding the percentage of pharmacy students who considered that they received formal training about tobacco cessation techniques at the university compared to the value obtained in 2014 (fig. 2).

The opinion of pharmacy students regarding the efficacy of different methods in tobaccology training is presented in figure 3. More than one third of the respondents consider

Table 3

ATTITUDES TOWARDS TOBACCO CONTROL POLICIES AMONG PHARMACY STUDENTS AT THE UNIVERSITY OF MEDICINE, PHARMACY, SCIENCE AND TECHNOLOGY, TARGU-MURES, ROMANIA

\begin{tabular}{|c|c|c|c|c|}
\hline \multirow{2}{*}{$\begin{array}{l}\text { Respondents } \\
\text { answered Yes to the } \\
\text { questions: }\end{array}$} & \multicolumn{3}{|c|}{$\mathrm{N}(\%)$} & \multirow[t]{2}{*}{$p$-value* } \\
\hline & 2014 & 2015 & 2016 & \\
\hline \multicolumn{5}{|c|}{ Should tobacco sales to adolescents (persons younger than 18 years old) be banned? } \\
\hline Yes & $405(97.8)$ & $376(95,4)$ & $439(97.6)$ & $\begin{array}{l}0.792 \\
\text { non-significant }\end{array}$ \\
\hline \multicolumn{5}{|c|}{ Should there be a complete ban of the advertising of tobacco products? } \\
\hline Yes & $351(84.8)$ & $331(83.8)$ & $384(84.8)$ & $\begin{array}{l}0.995 \\
\text { non-significant }\end{array}$ \\
\hline \multicolumn{5}{|c|}{ Should smoking be banned in restaurants? } \\
\hline Yes & $364(87.9)$ & $346(87.6)$ & $417(92.5)$ & $\begin{array}{l}0.024 \\
\text { significant }\end{array}$ \\
\hline \multicolumn{5}{|c|}{ Should smoking be banned in discos/bars/pubs? } \\
\hline Yes & $262(63.3)$ & $250(63.6)$ & $358(79.7)$ & $\begin{array}{l}0.0001 \\
\text { significant }\end{array}$ \\
\hline \multicolumn{5}{|c|}{ Should smoking in all enclosed public places be banned? } \\
\hline Yes & $324(78.3)$ & $315(79.7)$ & $379(83.7)$ & $\begin{array}{l}0.042 \\
\text { significant }\end{array}$ \\
\hline \multicolumn{5}{|c|}{ In your opinion is there any smoking at places where smoking is illegal? } \\
\hline Yes & $320(77.3)$ & $321(80.7)$ & $272(60.6)$ & $\begin{array}{l}0.0001 \\
\text { significant }\end{array}$ \\
\hline \multicolumn{5}{|c|}{ Do you agree to restrict smoking in the central building of the university, student dormitories, hospitals? } \\
\hline Yes & $392(94.7)$ & $368(92.8)$ & $420(93.6)$ & $\begin{array}{l}0.705 \\
\text { non-significant }\end{array}$ \\
\hline
\end{tabular}

${ }^{8} p=0.05$ (threshold for statistical significance). P value concerns the difference between $1^{\text {st }}$ and $3^{\text {rd }}$ study years. 
Table 4

THE EDUCATION, TRAINING AND THE ROLE AS A HEALTH PROVIDER

\begin{tabular}{|c|c|c|c|c|}
\hline \multirow{2}{*}{$\begin{array}{l}\text { Respondents who } \\
\text { answered Yes to the } \\
\text { questions: }\end{array}$} & \multicolumn{3}{|c|}{$\mathrm{N}(\%)$} & \multirow[t]{2}{*}{$p$-value* } \\
\hline & 2014 & 2015 & 2016 & \\
\hline \multicolumn{5}{|c|}{ Should health professionals get specific training on cessation techniques? } \\
\hline Yes & $386(93.5)$ & $366(92.7)$ & $414(91.4)$ & $\begin{array}{l}0.251 \\
\text { non-significant }\end{array}$ \\
\hline \multicolumn{5}{|c|}{ Do health professionals serve as "role models" for their patients and the public? } \\
\hline Yes & $324(78.3)$ & $302(76.5)$ & $332(73.5)$ & $\begin{array}{l}0.099 \\
\text { non-significant }\end{array}$ \\
\hline \multicolumn{5}{|c|}{ Should health professionals routinely advise their patients who smoke to quit smoking? } \\
\hline Yes & $382(92.3)$ & $355(89.9)$ & $403(89)$ & $\begin{array}{l}0.096 \\
\text { non-significant }\end{array}$ \\
\hline \multicolumn{5}{|c|}{ Should health professionals routinely advise their patients who use other tobacco products to quit using these products? } \\
\hline Yes & $375(90.6)$ & $334(84.8)$ & $394(87.2)$ & $\begin{array}{l}0.112 \\
\text { non-significant }\end{array}$ \\
\hline
\end{tabular}

${ }^{8} p=0.05$ (threshold for statistical significance). P value concerns the difference between $1^{\text {st }}$ and $3^{\text {rd }}$ year students.

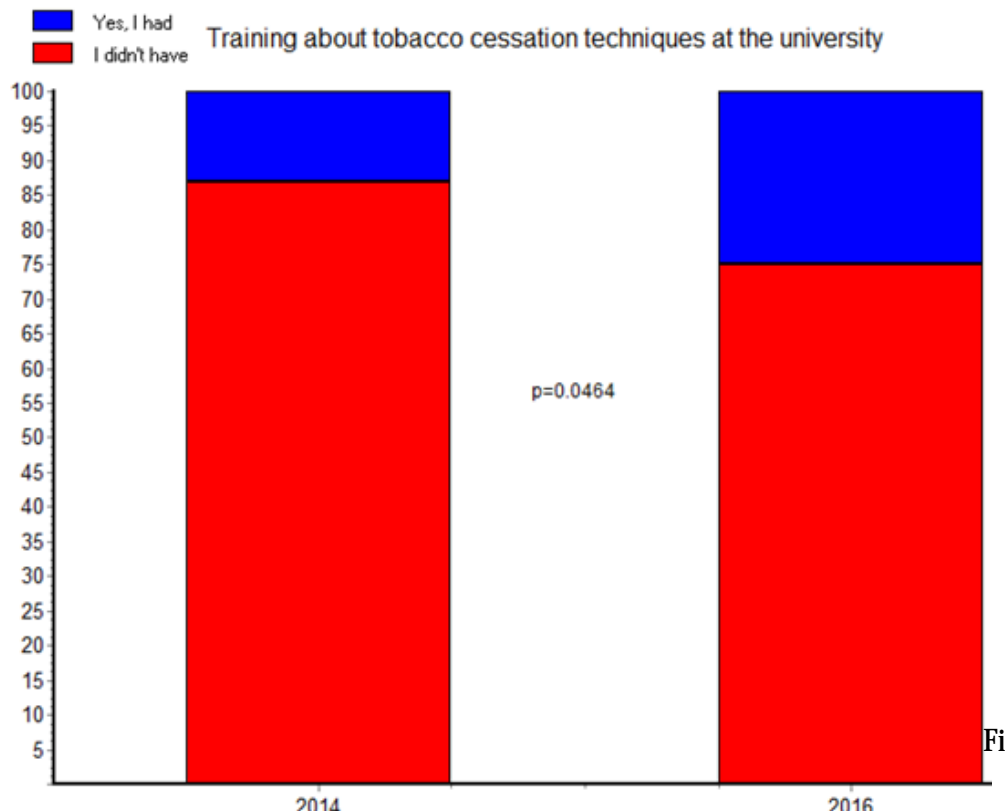

Methods of tobaccology training

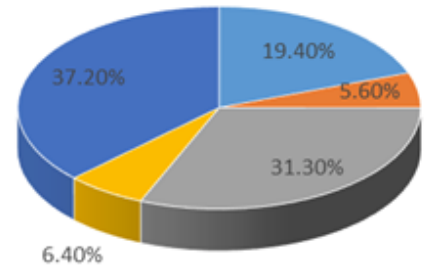

= Optional tobaccology course - Mandatory tobaccology course = Conference presentations by experts $=$ Workshops/volunteership - All of these

Fig. 3. Opinion of pharmacy students about efficient methods of tobaccology training

Fig. 2. Training about tobacco cessation techniques for pharmacy students

that a combination of different approaches would be most appropriate for efficient training.

Compared the smoker pharmacy students with smokers of medical and dental students we could observed the smallest occurrence in pharmacy students: $26-30 \%$, followed by students of dentistry $38.7 \%$ and medicine $59.6 \%$, respectively. The percentage in expressed willingness to quit smoking is $39.9 \%$ in medicine, $44.7 \%$ in dentistry and 95\% in pharmacy students [13].

When asked about exposure to passive smoke, an average of $36.5 \%$ of respondents reported being exposed to passive smoke in the central building of the university, $21.3 \%$ in the studentdormitories and $11.8 \%$ in the university hospitals, with a significant difference between the first and the fifth study years.

Fight against smoking through a variety of cessation methods can be effective especially by education in young people, including students [14]. Active and passive smoking, main causes of chronic obstructive pulmonary disease, lung cancer and cardiovascular disease, are present in high percentage in Mures County, according to our formerly published research data [15]. Smoking and exposure to indirect smoke was present in the buildings of our university during implementation of smoke-free policies in the previous years, and the amendments in the legislation due to the new national clean air law significantly improved air quality in our university campus [16].
According to recent data published by a local research group, smoking is very common in health professionals $(34.7 \%)$ compared to the whole country average in Romania (28\%). The knowledge of health professionals about the harmful effects of smoking is currently insufficient, however, they represent a good target group for anti-smoking activities as health promoters, having the potential to further educate large groups of patients [17].

This study focused on evaluating the smoking habits, know ledge about smoking and attitudes towards smoking cessation counselling of pharmacy students attending the University of Medicine, Pharmacy, Science and Technology in Targu Mures. Our study highlighted several important results including relatively low prevalence of smoking, positive attitudes towards tobacco control irrespective of own smoking status and a reasonable level of awareness of the university's non-smoking policy.

For pharmacists to be recognized as viable tobacco cessation providers, all pharmacy graduates must be equipped with the knowledge and skills to intervene with their patients who use tobacco. As such, all faculties of pharmacy should incorporate comprehensive tobacco cessation training within the required curriculum [18-23].

Besides advice related to cessation, dietary and medication-related recommendations are also important in counsel of smokers by health professionals, including pharmacists. High amounts of fiber intake with healthy food helps the detoxification of the body. Consumption of 
antioxidant vitamins from food or dietary supplements enhances the protection of the body from oxidative stress, which is intensified in smokers [24].

The study indicated that exposure to passive smoking showed a significant decrease until the end of the study and current smokers desire to quit was very high, ranging from $93.6-96.4 \%$. Thereby the study conducted for three years has very positive outcome.

\section{Conclusions}

This study provides new data on tobacco use among pharmacy students attending the University of Medicine, Pharmacy, Science and Technology of Targu Mures, Romania. It is the first study to our knowledge which has investigated smoking prevalence and attitudes within health professional students specialized in pharmacy at this university. However, surveys in this domain were conducted previously among dental students of the university $[25,26]$. The findings suggest that smoking prevalence among this cohort is low and that these health professional students are supportive of tobacco control policies. This three-year follow-up study and the efforts of our international research team had an important contribution in the implementation of the National Law 15/2016 in Romania and our institution became the first smoke-free medical university in Romania.

Acknowledgements: Research reported in this publication was supported by the Smoke-free medical university of Tirgu Mures: Principles, strategy, results of implementation 2012-2017"Project, and also Fogarty International Center and the National Cancer Institute of the National Institutes of Health under Award Number R01 TW09280. The content is solely the responsibility of the authors and does not necessarily represent the official views of the National Institutes of Health.

\section{References}

1.*** WORLD HEALTH ORGANIZATION. WHO report on the global tobacco epidemic 2017: Monitoring tobacco use and prevention policies, 2017, p.10, 16, 28.

2.*** WORLD HEALTH ORGANIZATION.Encouraging stopping smoking, WHO/MSD/MDP/01.4,http://www.who.int/mental_health/ evidence/stop_smoking_whomsdmdp01_4.pdf

3.*** WU, P., WILSON, K., DIMOULAS, P., MILLS, E.J ., Effectiveness of smoking cessation therapies: a systematic review and meta-analysis, BMC Public Health, 6, 2006, p. 300.

4.SYCHAREUN, V., HANSANA, V., CHOUMMANIVONG M., NATHAVONG S., CHALEUNVONG K., DURHAM J., Cross-sectional survey: smoking among medical, pharmacy, dental and nursing students, University of Health Sciences, Lao PDR, BMJ Open, 3, 2013, e003042.

5.SMITH, D.R., LEGGAT, P., An international review of tobacco smoking among medical students, J Postgrad Med, 53, 2007, p. 55-62.

6.CUMMINGS, K.M., GIOVINO, G., SCIANDRA, R., KOENIGSBERG, M., EMONT, S.L.R., Physician advice to quit smoking: who gets it and who doesn't, Am J Prev Med, 3, 1987, p. 69-75.

7.KUSMA, B., QUARCOO, D., VITZTHUM, K., WELTE, T., MACHE, S., MEYER-FALCKE A., RAUPACH, Berlin's medical students' smoking habits, knowledge about smoking and attitudes toward smoking cessation counseling, T., J Occup Med Toxicol, 5, 2010, p. 9.

8.GROUP T.G.C., The global tobacco surveillance system, Tob Control, 15, 2006, Suppl II, ii 31.

9.WARREN, C.W., SINHA, D.N., LEE J., LEA, V., J ONES, N.R., Tobacco use, exposure to secondhand smoke, and cessation counseling among medical students: cross-country data from the Global Health Professions Student Survey (GHPSS), 2005-2008, BMC Public Health, 11 (1), 2011, p. 72.

10.KIKELI, I.P., PREG, Z., NEMES-NAGY, E., GERMAN-SALLO, M., BALINT SZENTENDREY D., FAZAKAS Z., SZILVESZTER, M., IANOSI, E.S., LASZLO, M.I., BALAZS, P., Chapter 5. Proiectul Universitatea medicala Tirgu Mures libera de fumat - Principii, strategie, rezultatele implementarii 2012-2017 (Smoke-free medical university - Tirgu Mures, Principles, strategy, results of implementation 2012-2017). In: ABRAM, Z., NADASAN, V., Dezvoltarea capacitatii de cercetare in domeniul fumatului in Romania (Developing smoking research capacity in Romania). Editura University Press, Targu Mures, 2018, p. 106-144.

11.*** Ghid privind implementarea Legii nr. 15/2016 pentru prevenirea si combaterea consumului produselor din tutun. http://gov.ro/fisiere/ stiri_fisiere/16-03-16-03-33-55Ghid_legea_15_pe_2016.pdf

12. ${ }^{*} * *$ List of smoking bans. https://en.wikipedia.org/wiki/ List_of_smoking_bans

13.PREG, Z., IANOSI, E.S., NEMES-NAGY, E., LASZLO, M.I, FAZAKAS, Z., GERMAN-SALLO, M., BALINT-SZENTENDREY, D., ABRAM, Z., BALAZS, P., FOLEY, K.L., KIKELI, P.I., Tobacco use, exposure to secondhand smoke, and smoking cessation counselling among medical students from the University of Medicine and Pharmacy from Targu-Mures -baseline data of the first Smoke-Free Medical University Project, Pneumologia, 66 (3), 2017, p. 133-139.

14.IANOSI, E.S., POSTOLACHE, P., MACOVEI, L.A., SZATHMARY, M., SZASZ, S., NEMES, R.M., JIMBOREAN, G., Smoking Cessation in COPD Patients by a Selective Partial Nicotinic Agonist, Rev. Chim. (Bucharest), 69, no. 7, 2018, p. 1760-1765.

15.BALINT., I., NEMES-NAGY, E., CSIBI, M., TUBAK, N., OLAH, P., PREG, Z., GERMAN-SALLO, M., TILINCA, M., ABRAM, Z., FAZAKAS, Z., The role of diet and lifestyle habits in prevention of cardiovascular disease in Moldavian and Transylvanian population, Rev. Chim. (Bucharest), 68, no. 7, 2017, p. 1460-1465.

16.NEMES NAGY, E., PREG, Z., LASZLO, M.I., VOIDAZAN, S., FAZAKAS, Z., GERMAN SALLO, M., ABRAM, Z., BALAZS, P., FOLEY, K., KIKELI, P.I., The Influence of the New National Clean Air Law on the PM2.5 Air Pollution in the Campus of the UMPh Tirgu Mures During the Implementation of the Smoke-free University Project, Rev. Chim. (Bucharest), 68, no. 8, 2017, p. 1820-1824.

17.IANOSI, E.S., DANTES, E., CSIPOR, A., SZATHMARY, M., SOCACl, A., RUSU, E., NEMES, R.M., Enchancing Education for Smoking Preventing and Smoking Cessation in Medical Personnel. A measure for a better health, Rev. Chim. (Bucharest), 69, no.10, 2018, p. 2725-2727.

18.MC BANE, S.E., CORELLI, R.L., ALBANO, C.B., CONRY, J.M., DELLA PAOLERA M.A., KENNEDY, A.K., HUDMON, K., The role of academic pharmacy in tobacco cessation and control. American journal of pharmaceutical education, Am J Pharm Educ., 77 (5), 2013, p. 93.

19.HUDMON, K.S., BARDEL, K., KROON, L.A., FENLON, C.M., CORELLI, R.L., Tobacco education in US schools of pharmacy, Nicotine Tob Res., 7 (2), 2005, p. 225-232.

20.WILLIAMS, D.M., Preparing pharmacy students and pharmacists to provide tobacco cessation counselling, Drug and alcohol review, 28 (5), 2009, p. 533-540.

21.BOCK, B.C., HUDMON, K.S., CHRISTIAN, J., GRAHAM, A.L., BOCK, F.R., A tailored intervention to support pharmacy-based counseling for smoking cessation, Nicotine \& tobacco research, 12 (3), 2010, p. 217-225.

22.LEONG, S.L., LEWIS, P.R., CURRY, W.J., GINGRICH, D.L., Tobacco world: evaluation of a tobacco cessation training program for thirdyear medical students, Academic Medicine, 83 (10), 2008, S25-S28. 23.NADASAN, V., FOLEY, K.L., PENZES, M., PAULIK, E., MIHAICUTA, S., ABRAM, Z., BALINT, J., URBAN, R., Use of electronic cigarettes and alternative tobacco products among Romanian adolescents, Int J Public Health, 61 (2), 2016, p.199-207.

24.TARCEA, M., FAZAKAS, Z., SZUCS, V., KOVACS, ZS., NEMES-NAGY, E., OLAH, P., TILINCA, M., GUINE, R.: Mean Dietary Fiber Intake of Romanian Adults. Results of a Survey Questionnaire, Rev. Chim. (Bucharest), 68, no. 9, 2017, p. 2083-2087.

25.SZEKELY, M., FAZAKAS, Z., Dohanyzasi szokasok a Marosvasarhelyi Fogorvostudomanyi Kar es Fogtechnikai Kollegium hallgatoi koreben. Orvostudomanyi Ertesito, 76 (3), 2003, p. 453-456.

26.BENEDEK (BUKHARI), C., KEREKES-MATHE, B., BORS, A., KOVACS, M., POP, M., FAZAKAS, Z., SZEKELY, M., Smoking related habits and attitudes of dental students. Acta Medica Marisiensis, 58 (5), 2012, p. 266-271.

\section{Manuscript received: 15.01 .2019}

